\title{
Literature Review on REITs and Islamic REITs and Lessons Learned for Islamic REITs in Indonesia
}

\author{
Imam Wahyudi Indrawan \\ International Islamic University Malaysia, Malaysia, indrawan.imam@live.iium.edu.my
}

Wahyuningsih

Universitas Indonesia, Indonesia, wahyuningsihayu75@gmail.com

Article History

Received: April 11, 2019 Revised: June 18, 2019 Accepted: July 8, 2019

\begin{abstract}
Real Estate Investment Trusts (REITs) as a new instrument in many capital markets is an interesting topic. Although not yet to be popular globally, REITs has gained popularity as flexible, cost efficient and profitable real estate investment vehicle for investors as well as provide liquidity for real estate sector, especially in advanced markets like in US, Japan and Singapore. The emergence of Islamic Financial Institutions (IFIs) coincided with increasing popularity of REITs open opportunity for development of Islamic REITs (I-REITs) as competitive but sharia compliant REITs compared to the conventional one. The dominance of Malaysia as market player of I-REITs as well as many underresearched areas open opportunity for betterment of the current I-REITs markets. This paper is a literature review with two objectives. First, to compile and review existing articles on REITs, both conventional and Islamic, and second, to gain lesson learned as material for development of I-REITs in Indonesia as ultimate goal. It is expected that this literature review will generate ideas for future development proposals on I-REITs, particularly in Indonesia. This study found that literature on I-REITs is relatively thin compared to its conventional counterparts, and Indonesia is still left behind in I-REITs development despite regulatory framework is already in force. Therefore, further effort to promote supply and demand of I-REITs in Indonesia should be taken as a way to diversify Islamic investment avenues for sharia oriented investors.
\end{abstract}

Keywords: Indonesia, Islamic REITs, literature review, Real Estate Investment Trusts (REITS).

JEL Classification: G23, N20

@ IJIEF 2019 published by Universitas Muhammadiyah Yogyakarta, Indonesia All rights reserved

DOI:

https://doi.org/10.18196/ijief.2114

Web:

http://journal.umy.ac.id/index.php/ijief/article/view/6132

Citation:

Indrawan, I. W., \& Wahyuningsih. (2019) Literature Review on REITs and Islamic REITs and Lessons Learned for Islamic REITs in Indonesia. International Journal of Islamic Economics and Finance (IJIEF), 2(1), 21-46. Doi: https://doi.org/10.18196/ijief.2114. 
Indrawan \& Wahyuningsih | Literature Review on REITs and Islamic REITs and Lessons Learned for Islamic REITs in Indonesia

\section{Introduction}

Real Estate Investment Trusts (REITs) is a relatively new topics in many capital markets. Although it has been introduced in 1960 in the United States (US), there are some markets especially in emerging economies that do not have any company listed as REITs, such as China and even most European countries (Campbell \& Sirmans, 2002; Quek \& Ong, 2008). Despite that, REITs is perceived to be a good vehicle to invest in real estate sector with advantage but flexibility as Unit Trusts, as well as providing liquidity to support the developer of real estates. Thus, REITs is attractive for many investors. Currently, the global REITs market capitalization has reached US\$ 1.7 trillion with $7 \%$ growth in 2018, with US as the main driver of growth with $10 \%$ growth in its REITs market that already reched US\$ 1.15 trillion market capitalization (EY, 2018).

The emergence of Islamic Financial Institutions (IFIs), such as Islamic Banks and Islamic Capital Markets also influenced market players to also have the so called Islamic REITs (I-REITs), REITs with consideration on the sharia compliant issue of the business as alternative for its conventional counterpart. Since its emergence of Al-'Aqar KPJ REITs, the first I-REITs in the world that based in Malaysia in 2006, there are some I-REITs emerged and try to catch up the performance of the conventional REITs (Osmadi and Razali, 2014; Hussin, Husaini, Muhammad, Razak, and Hadi, 2016).The biggest I-REITs today is Emirates REITs with market capitalization of US\$333 million, although Malaysia is still the dominant I-REITs market in the world with market capitalization around RM 2.6 billion (US\$ 637.44 million) (Mohamad \& Saad, 2012; Zainuddin \& Nordin, 2016).

Although there are many studies that try to analyzed conventional REITs and some studies on I-REITs, such as Chuweni and Ahmad (2014); Nadiah, Ali, Halim, and Noor (2016); Rozman, Azmi, Ali, and Razali (2015); and Osmadi and Razali, 2014; Hussin, Husaini, Muhammad, Razak, and Hadi(2016), but literature review that on this issue is still lacking. There are some literature review on conventional REITs, such as Corgel, Mcintosh, \& Ott (1995), but in author's best knowledge, literature review on both REITs (conventional and Islamic) is none. This paper is a literature review on both conventional and Islamic REITs with objective to provide reader the latest development on studies on both REITs in general, with ultimate goal to find state of art on the studies and to gain lesson learned for I-REITs from its conventional counterpart in order to enhance listing of new I-REITs and improve the performance of existing I-REITs. More specifically, this kind of study is important since I-REITs is non-exist yet in Indonesia, although the regulatory framework for I-REITs is already in force and even practically, Malaysia based Al-'Aqar KPJ REITs has investment in Indonesian hospital (Najeeb \& Vejzagic,

IJIEF: International Journal of Islamic Economics and Finance, 2(1), 21-46 | 22 
Indrawan \& Wahyuningsih | Literature Review on REITs and Islamic REITs and Lessons Learned for Islamic REITs in Indonesia

2013). In other words, there is a potential for development of I-REITs in Indonesia that can be realized. Thus, this kind of study is expected to provide insights that may lead to enhancement of I-REITs in Indonesia.

This paper is dividied into four sections. First section is the introduction which describe the background and objective of the study. Second section focus on the methodology of the literature survey and review. Third section is the literature review based on categorization of literatures. Fourth section is the concluding remarks with some lessons learned for potential future studies on I-REITs from literatures reviewed.

\section{Literature Review}

\section{Theory}

\section{Conventional REITs}

REITs can be defined as companies that buy, develop, manage, and sell real estate properties with the revenue from real estate related business will be distributed nearly all to the the company's shareholders or Unit holders (Chiang \& Joinkey, 2006). REITs can be seen as companies that provide hybrid investment vehicle that combine (unsecuritized) real estate and common stocks characteristics but with lower volatility (Alias \& Y, 2011; J. Kim \& Jang, 2012). REITs originally created in 1960 by approval from US Congress as an instrument to enhance liquidity and improve efficiency as well as performance on the real-estate sector (Campbell \& Sirmans, 2002).

One reason behind REIT existence is to provide a tax-efficient vehicle for commercial real estate ownership, because high tax will decrase REIT market competitiveness compared to other countries, and existence or REIT market will bring expertise that will attract many investors, which in turn will enhance marketability of nation's real estate (Quek \& Ong, 2008). REITs is also able make individual investors to have real estate indirectly by purchasing REITs' shares that mostly traded in the exchanges (Alias \& $Y$, 2011).

\section{Islamic REITs}

Islamic REITS (I-REITS) is a recent financial vehicle in the Islamic finance universe. Securities Comission (SC)of Malaysia defined I-REITs as "a collective investment scheme in real estate, in which the tenants operate permissible activities according to the sharia". From this definition, it can be concluded that the main feature that differentiate I-REITs from its conventional counterpart is the obligation to follow the sharia or Islamic law, particularly on the operation of the tenants. Malaysia in 2005 issued guidelines on IREITs and the first I-REITs listed on Kuala Lumpur Stock Exchange (KLSE) in 
Indrawan \& Wahyuningsih | Literature Review on REITs and Islamic REITs and Lessons Learned for Islamic REITs in Indonesia

2006, making Malaysia as the first jurisdiction to issue guidelines and establish I-REITs as well as the largest I-REITs market by far, with market capitalization around RM 2.6 billion (USD 637.44 million), representing around $14.2 \%$ share of Malaysia's domestic REITs market (Mohamad \& Saad, 2012; Zainuddin \& Nordin, 2016).

\section{Comparison Between Conventional REIT and Islamic REIT}

In its operation, I-REITs does not differ from the conventional REITs. Both types of REITs will gain two sources of income stream from the properties, i.e. rental income and capital appreciation. Both REITs also give potential return for the investors in form of dividend and capital gain, that distributed from realized gains or income from the properties. However, I-REITs will only allow the tenants of the properties to conduct sharia compliant activities, or the jurisdiction may put certain benchmark as upper limit for non-sharia compliant activities and income for I-REITs, let say $20 \%$ of the total income as for the case of Malaysia (Mohamad \& Saad, 2012).

\section{Previous Studies}

Scholars have conducted several studies to survey the literature on Islamic finance, either as a whole or partially. A study by Hassan and Aliyu (2018) focuses on Islamic bank sustainability, while another study by Zulkhibri (2015) discussed the nature and operational aspect of sukukand its impact towards economic growth. A more comprehensive study conducted by Mukhlisin and Komalasari (2018) covering 330 literatures on the universe of Islamic finance, including Islamic banking, takaful, Islamic capital market, unit trust fund and Islamic endowment (waqf) from 1983 to 2017 with more emphasis on how those literatures capture the effect of financial crises on Islamic finance. However, none of the aforementioned studies put I-REITs as their focus of the study as well as its comparison with the conventional counterpart. Therefore, this study would focus on REITs and I-REITs with emphasis to provide insights for development of I-REITs in Indonesia.

IJIEF: International Journal of Islamic Economics and Finance, 2(1), 21-46 | 24 
Indrawan \& Wahyuningsih | Literature Review on REITs and Islamic REITs and Lessons Learned for Islamic REITs in Indonesia

\section{Methodology}

In order to conduct this literature survey, some websites of scientific works database are accessed to find relevant articles on REIT. The websites browsed with the keywords are shown on the following table:

Table 1. Websites and Keywords for Literature Survey

\begin{tabular}{|l|l|}
\hline \multirow{4}{*}{ Websites } & 1) Emerald Insight (www.emeraldinsight.com) \\
& 2) Science Direct (www.sciencedirect.com) \\
& 3) Ebscohost (https://search.ebscohost.com) \\
& 4) Google Scholar(https://scholar.google.com) \\
\hline \multirow{5}{*}{ Keywords } & 1) Real Estate Investment Trust \\
& 2) REIT \\
& 3) Islamic Real Estate Investment Trust \\
& 4) Islamic REIT \\
5) REIT Indonesia
\end{tabular}

Some criteria are set in order to give limitation on this literature survey. First, an article must be found and accessible on above websites.Second, an article must be published at year 2000 or afterwards. An article that published prior to year 2000 (1999 or before) will not be part of the literature survey.After filtering the articles with above criteria, there are 75articles that proceed for literature survey process. The articles are grouped into following categories:

Table 2. Classification of the Literature on REITs and I-REITS

\begin{tabular}{|c|c|c|}
\hline No. & Category & Description \\
\hline 1 & $\begin{array}{l}\text { Understanding REITs } \\
\text { (Structure and } \\
\text { Characteristics) }\end{array}$ & $\begin{array}{l}\text { Any article falls within this category must contains } \\
\text { description of any (conventional) REITs structures } \\
\text { and characteristics. Some articles with } \\
\text { quantitative method but does not discuss on } \\
\text { performance, such as comparing cost structures of } \\
\text { some REITs also included within this category. }\end{array}$ \\
\hline 2 & $\begin{array}{l}\text { Regulatory Framework of } \\
\text { REITs }\end{array}$ & $\begin{array}{l}\text { Articles within this category must explain some } \\
\text { aspects of regulatory framework for } \\
\text { (conventional) REITs from any jurisdictions. }\end{array}$ \\
\hline 3 & REITs Performance & $\begin{array}{l}\text { Articles that examine performance, including } \\
\text { returns and volatility of (conventional) REITs fall } \\
\text { within this catogory. Most quantitative works are } \\
\text { categorized here. }\end{array}$ \\
\hline 4 & Islamic REITs & $\begin{array}{l}\text { Any articles that discuss any aspects of Islamic } \\
\text { REITs are included within this category. }\end{array}$ \\
\hline
\end{tabular}

IJIEF: International Journal of Islamic Economics and Finance, 2(1), 21-46 | 25 
Indrawan \& Wahyuningsih | Literature Review on REITs and Islamic REITs and Lessons Learned for Islamic REITs in Indonesia

Table above shows that studies on conventional REITs are classified into three groups. However, some of the papers may have more than one focus, hence they can be classified into more than one groups. Meanwhile, studies Islamic REITs are included into one group only regardless of their focus. In addition to the literature review, this paper also addresses critical evaluation on REITs' regulatory framework and development in Indonesia as well as taking lesson learned for development of Islamic REITs (I-REITs) in Indonesia, which is still non-exist yet.

\section{Results and Analysis}

\section{Results}

\section{Mapping the Literature on REITs}

Out of 75 papers found related on REITs and Islamic REITs, there are only nine of them discussed Islamic REITs. Most studies of Islamic REITs focus on the case of Malaysia. Meanwhile, majority of papers on conventional REITs try to focus on the REITs performance, although there are some papers that have more than one focus. The mapping of the literature is shown on the following table:

Table 3. Mapping of the Literature on REITs and I-REITs

\begin{tabular}{llc}
\hline No. & \multicolumn{1}{c}{ Category } & Number of Literature \\
\hline 1 & Understanding REITs (Structure and Characteristics) & 14 \\
2 & Regulatory Framework of REITs & 6 \\
3 & REITs Performance & 53 \\
4 & Islamic REITs & 9 \\
\hline
\end{tabular}

\section{Understanding REITs (Structure and Characteristics)}

There are three key elements of REITs, particularly the US REITs: i) REITs' assets and revenues should be dominantly in form of real-estate, with little proportion of securities; ii) REITs are usually non-corporate taxable although most of the are public companies. This is important as key point to avoid double taxation; iii) all accounting earnings must be distributed to the shareholders, making it taxable at investor level. In other words, REITs will give the shareholders similar features like Unit Trust but with smaller tax, without double taxation, and lower transaction cost compared to direct investment on real estate. REITs in US can be divided into two categories. First, mortgages REITs that focus on originating and/or acquiring mortgages. Second, equity REITs that focus on real-estate direct investment (Campbell \& Sirmans, 2002).

There are some obstacles that still inhibit the growth of REITs especially in 
Indrawan \& Wahyuningsih | Literature Review on REITs and Islamic REITs and Lessons Learned for Islamic REITs in Indonesia

emerging markets. Study by (Quek \& Ong, 2008) found six REIT development obstacles in China: 1) Security of property legal title because vendor may disappear or use the money from investor for other purposes instead of real estate investment; 2) China is still lacking professional and asset management experts; 3) Different property valuation method between Chinese vendors (market comparable approach) with international practices (discounted cash flow approach); 4) China is still lacking market transparency; 5) No regulatory framework for REIT in China; 6) High tax imposition by Chinese government to foreign investors, such as value-added tax, enterprise income tax, and land appreciation tax. The Chinese case is very different from its Special Administrative Region (SAR), Hong Kong that has a notable REITs market. One notable REIT in Hong Kong is called "Link", the first and dominant REIT in Hong Kong, established in 2005 and currently has various real estate portfolios such as retail facilities and car parks (Chiang \& Joinkey, 2006; Hui, Yiu, \& Yau, 2007).

Another important consideration to be taken in introducing REITS instruments into the market is the cost of REITs unit issuance, particularly the underwriting discount cost. A study by (Bairagi \& Dimovski, 2012b) on US Seasoned Equity Offerings (SEOs) REITs that there are some significant determinants of underwriting discount cost, such as dollar offer price per share, gross proceeds, interest rate on US 10 year-treasury bill, and number of total underwriters and number of representative underwriters. Authors suggestion to enhance efficiency of SEOs REITs issuance is by stating that issuers can allocate underwriting process among some underwriters. Meanwhile, study by (Bairagi \& Dimovski, 2012a) that focus REITs IPO direct cost echoed similar statement, that distributing underwriting business to several underwriters will reduce direct cost of REITs IPO.

With regard to capital structure, REITs as public should also raise capital to finance its operation. Study from (Dong, 2012) found that Listed Property Trusts (LPTs), name for REITs in New Zealand, tend to reduce long-term debt in its capital structure when there is appreciation on New Zealand dollar one-year forwards rate because it will favour LPTs to get short-term debt overseas with foreign currency, thus shrinking long-term debt leverage. However, REITs with high market valuation tend to have persistent and high leverage (Feng, Ghosh, \& Sirmans, 2007).

Meanwhile, for the ownership structure, many REITs can be categorized as Umbrella Partnership REITS (UPREITS). UPREITs is a form of REITS that have dual ownership structure, comprising common shares and Operating Partnership Units (OP units). OP Units is a vehicle that enable UPREITs to defer unit holders' capital gain tax because as long as OP Units are hold as well as the real estate contributed, the unit holders' will get deferment capital gain tax, and make OP unit holders has tax advantage over common 
Indrawan \& Wahyuningsih | Literature Review on REITs and Islamic REITs and Lessons Learned for Islamic REITs in Indonesia

shareholders. However, UPREITs dual ownership may raise conflict of interest between shareholders and unit holders as well as agency problem(Han, 2006).

In general, we can conclude that REITs is an attractive and flexible vehicle for real estate investment, given the market infrastructures are provided. Cost efficiency and tax advantage are two main issues that must be solved prior to emergence of well-performed and liquid REITs market.

\section{Regulatory Framework of REITs}

Regulatory framework is important part on developing REIT market, that even to some extent regulation aspect is the most distinct feature of REITs market in each jurisdictions (Alias \& Y, 2011). There are some studies that have tried to look at the regulatory framework of REITs in various jurisdictions(Alias \& Y, 2011; Campbell \& Sirmans, 2002; Chiang \& Joinkey, 2006; Pellerin, Sabol, \& Walter, 2013; Quek \& Ong, 2008).

Currently, there are some jurisdictions with strong REITs market presence. They are US, Australia, Japan, South Korea, Singapore and Taiwan. With regard to the regulatory framework, all these countries have some common REITs regulatory features. First, REITs companies are required to have dominant portion of their portfolio in real estate related assets. In South Korea and Singapore, real estate must be at least 70\% of REITs' assets, $75 \%$ in US and Japan and $100 \%$ in Australia. Second, requirement to distribute almost all of REITs' revenues to shareholders or Unit holders. It is $100 \%$ in Australia and Singapore, $90 \%$ in Japan as well as South Korea with Korean REITs will gain tax exemption if the requirement fulfilled. Third, tax advantage of REITs from zero corporate tax if most revenues are distributed (US), tax redemption for real estate acquistions and registrations (Japan), tax deferment for investors (Australia), and zero income tax for investors (Taiwan). Fourth, geogrpahical location of real estate assets with most jurisdictions do not have restrictions for geographical location of REITs' properties to enhance flexibility of their investment. Fifth, leverage cap with some imposed certain cap such as $45 \%$ in Hong Kong, but some (US, Australia, South Korea and Japan) do not have any leverage restrictions(Chiang \& Joinkey, 2006).

While REITs is a popular instrument in US and has been contributed to US real market liquidity and efficiency, Europe, on the other hand is still left behind in developing REITs market. With only The Netherlands, United Kingdom, and Belgium as European countries with REITs-like company up to 2007, there are some issues related to European regulatory framework of REITs such as restrictions on REITs ownership concentration, size of 
Indrawan \& Wahyuningsih | Literature Review on REITs and Islamic REITs and Lessons Learned for Islamic REITs in Indonesia

permitted ownership for institutional investors, portion of accounting earnings to be paid as dividends, and ease of de-REIT (close the REITs) and re-REIT (open REITs again), and the scope of REITs operation in cross-border Europe (Alias \& Y, 2011; Campbell \& Sirmans, 2002).

At the same time, China as the new giant of world economy does not have regulatory framework to regulate it, thus making REIT market still does not exist in China(Quek \& Ong, 2008). Meanwhile, Malaysia with smaller economic size compared to China has rapid development of REITs market that also complemented with product variant, particularly Islamic REITs (Hamzah, Rozali, \& Tahir, 2010). In general, regulatory framework that must be developed for a REITs market must solve some issues, such as tax transparency which if possible having tax advantage to enhance REITs market competitiveness, legal titles, market transparency, property valuation method and expertise.

\section{REITs Performance, Risk and Volatility}

Basically, REITs performance is relied on tax advantage and Fair Value Accounting (FVA) practices (Haslam, Tsitsianis, Andersson, \& Gleadle, 2015). Tax advantage is the most attractive feature of REITs since this feature give REITs higher benefits for investors compared to direct real-estate investment. In return, REITs will generate higher liquidity into real-estate market. Less tax advantage will reduce REITs competitiveness, especially in a globalized market. FVA practices is also an important role in REITs performance because it gives transparent image on the value of real-estate portfolio and enable REITs managers to observe the portfolio value directly from real estate value. However, FVA practices also cause REITs will exposed to real estate sector volatility, which is reasonable because real estate assets are REITs' main underlying assets. One of the effects of REITs performance is the institutional investors intention to invest through REITs, especially REITs with high volume of transaction (Al-Haj \& Hashim, 2009).

Many studies have tried to investigate the behavior of REIT performance. One of the most common scope ofstudies in REITs performance is comparing performance of one or some REITs companies within one jurisdiction (Akinsomi, Ong, Ibrahim, \& Newell, 2016; Aro-gordon, 2015; Asteriou \& Beigazi, 2013; Bene, Anderson, \& Zumpano, 2009; Brown, 2000; Compton, Johnson, Kunkel, \& Compton, 2006; Escobari \& Jafarinejad, 2016; Hartzell, Kallberg, \& Liu, 2008; Hartzell, Sun, \& Titman, 2014; Ho \& Tay, 2016; Huerta, Jackson, \& Ngo, 2015; Larson, 2005; C. Lee, Chien, \& Lin, 2012; Liow \& Addae-dapaah, 2010; Lu, Chen, \& Liao, 2014; Olanrele, Said, \& Daud, 2014; Pellerin et al., 2013; Quek \& Ong, 2008; San, Heng, \& Pong, 2011; Yung, Li, \& Jian, 2017), with USA market is the most studied so far, which is not

IJIEF: International Journal of Islamic Economics and Finance, 2(1), 21-46 | 29 
Indrawan \& Wahyuningsih | Literature Review on REITs and Islamic REITs and Lessons Learned for Islamic REITs in Indonesia

surprising because USA REITs market is the mature one in the world. One example is a study by (Brown, 2000) found that mortgage REITs that financed real estate investment using financial leverage had deeper negative returns compared to equity REITs that financed the investment directly.

Meanwhile, study (Quek \& Ong, 2008) that based in China, which does not have regulatory framework. Therefore, REITs that operated with Chinese property as underlying asset are Hong Kong based GZI REIT and Singapore based Capita Return China Trust (CRCT). This study found that both REITs were performed well during their respective IPO, but CRCT can outperformed GZI and some other Singaporean REITs after IPO, while GZI still left behind even in Hong Kong REIT market. Despite their different performance, performance of these two REITs indicates strong demand for REITs in China.

Some of studies are also comparing REITs in different jurisdictions (Alexander, Cheng, Rutherford, Springer, \& Alexander, 2013; Alias \& Y, 2011; Brobert, 2016; Ho, Addae-dapaah, \& Peck, 2017; C. L. Lee \& Lee, 2012; Loo, Anuar, \& Ramakrishnan, 2016; Mi, Benson, \& Faff, 2016; Olanrele, Said, \& Daud, 2015; Seiler, Lee, \& Seiler, 2003; I.-C. Tsai \& Lee, 2012; I. Tsai, 2013; Yeboah, Ling, \& Naranjo, 2012). One example is a study by (Alias \& Y, 2011) that compared performance of Malaysian REITs and UK REITs found several factors that affect REITs performance in these two markets. First, the rental revenue from the real estate tenants, which in turn becomes the dividends for REITs'Unit holders. Second, type of real estate property will determine the revenue generated with following order from the highest to the lowest: i) retail commercial properties; ii) office properties; iii) residential properties; iv) industrial properties.

Meanwhile, another study by (I.-C. Tsai \& Lee, 2012) found an interesting finding. By CIPS or Pesaran test method, this study found that the returns of Asian REITs markets (Singapore, Hong Kong, Malaysia, Thailand, Taiwan, and Korea) are more converged to the performance of US REITs market compared to Japan's market returns. This finding indicates that the behavior or REITs investors are tend to be irrational and influenced by nonfundamental issues. To comprehend our view, a study from (Sah \& Seagraves, 2012) found that in US REITs market, there is no significant evidence that clustering REITs IPO time in will give different performance in terms of operating measures (operating return on total assets (OROA), net return on total assets (NRTA) and total assets turnover ratio (TATRs)). This is due to US market's transparency which means very little assymetric information between managers and investors. By comparing between these two studies, REITs investors in emerging markets like in Asia is still irrational compared to their counterparts in mature market like USA, and difference between the two is due to differences in market transparency which is 
Indrawan \& Wahyuningsih | Literature Review on REITs and Islamic REITs and Lessons Learned for Islamic REITs in Indonesia

related to the regulatory framework.

Other studies focus on comparison of REITs performance between before and after certain events, such as real estate downturn and Global Financial Crisis (GFC) (Brown, 2000; Campbell \& Sirmans, 2002; Dimovski, Ratcliffe, \& Keneley, 2017; M. Lee \& Lee, 2003). In post Global Financial Crisis (GFC) 2008, real estate sector suffered from huge impact of the crisis, including the REITs. Thus, there are many cases where post-GFC REITs were looking to merger or acquire other REITs. Study from (Ratcliffe \& Dimovski, 2012) on several bidders (acquirers) and targets (acquirees) found that targets gained higher wealth after the merger or acquisition, while for bidders, they will gain higher if the targets are private companies and tend to suffer loss of wealth when acquiring targets that listed as public companies. GFC also gave impact to REITs IPO, that most REITs IPO in post-GFC period tend to be underpriced (Dimovski et al., 2017). Another study by (Campbell \& Sirmans, 2002) found that REITs companies in US market gained momentum after 1986 tax reforms that removed tax advantage of real estate limited partnerships (RELPS), a real estate investment vehicle other than REITs, making REITs as vehicle that had the most advantage for real estate investment.

There are also some studies that tried to compare the performance of REITs with other instruments, (Ivanov, 2016; H. Kim, Gu, \& Mattila, 2002; C. L. Lee \& Ting, 2009; M. L. Lee \& Chiang, 2010; Olaleye \& Ekemode, 2014; Piao, Mei, \& Zhang, 2017; Waggle \& Moon, 2006), with most of them compared REITs performance with common stocks and Exchange Traded Funds (ETF). Study by (M. L. Lee \& Chiang, 2010) found that between 1978 to 2008, REITs performance has two distinct phase. Prior to early 1990s structural break, REITs performance in the long run behaved like common stocks. Meanwhile, after the structural break, REITs performance behaved in opposite direction with common stocks and parallel with real estate performance, in the long run. Meanwhile, in case of Malaysia, REITs has been found to bring more diversification benefits with returns improvement and/or risk reduction for mixed-portfolio investors compared to listed property company's shares, which means REITs can be a good vehicle for real estate investors(C. L. Lee \& Ting, 2009).

There is also a unique study by (Ho, Rengarajan, \& Lum, 2013) on the effect of green building into REITs performance in Singapore. This study found that if REITs has higher greenness, that measured by the percentage of square feet of certified properties and the average "greenness" score, will yield better operational and financial performance. This is an important finding which indicates that REITs can play its role together with Socially Responsible Investment (SRI). 
Indrawan \& Wahyuningsih | Literature Review on REITs and Islamic REITs and Lessons Learned for Islamic REITs in Indonesia

Another sub-category is studies that looking for the impact of macroeconomic variables to REITs performance or macroeconomic policy such as The Fed's Taper Tantrum to REITs market (Ewing \& Payne, 2005; S. Lee, 2016; Loo et al., 2016). Studies found that macroeconomic policy and variables have fundamental and long-run relationship with performance of REITs markets, with usually any shocks will tend to lower the REITs returns compared to investors' expectation. There is also a study by (Nazlioglu, Gormus, \& Soytaş, 2016) that found oil price shocks will generate volatility in various REITs sectors (Residential, Hotel, Healthcare, Retail, and Warehouse/Industrial REITs).

\section{Islamic REITs}

Number of literatures on Islamic REITs (I-REITs) is not quite much. Within author's database, there are only 14 literatures on I-REITs, compared to 61literatures on conventional REITs.All of literatures in I-REITs are published in 2010 or after. Most of the literatures are focusing on Malaysian I-REITs (Chuweni \& Ahmad, 2014; Chuweni \& Eves, 2017; Mohamad \& Saad, 2012; A. Osmadi \& Razali, 2014; Rozman, Azmi, Ali, et al., 2015; Rozman, Azmi, Razali, \& Ali, 2015; Teh, Soh, \& Yan, 2012; Yahya et al., 2016; Zainuddin \& Nordin, 2016), which is not surprising since the first I-REITs in the world, the Al 'Aqar KPJ REIT is based in Malaysia(Najeeb \& Vejzagic, 2013). Other papers are studied the case of GCC (Gulf Cooperation Council) REITs (Akinsomi et al., 2016; Ibrahim, Ong, \& Akinsomi, 2012) with one study on cross-jurisdictions REITs comparison between Malaysia and GCC (Ma'in et al., 2016)

Above I-REITs related papers can be further categorized into some subcategories. First, policy and conceptual paper which tried to explain the nature of I-REITs (Lewis, 2010), which basically explained I-REITs together with other Islamic funds. Also falls within this sub-category is a study by(Ibrahim et al., 2012) that underlined some sharia guidelines on I-REITs, particularly requirement of sharia assessment, limitation of revenues from non-permissible activities by tenants at maximum $20 \%$ of total rental revenues of I-REITs and all financial operations (deposit, investment and financing) must be sharia compliant.

Next category is studies that focus on governance of I-REITs. There are two studies which focusing on Malaysian I-REITs governance and they conclude that current Malaysian I-REITs' governance is in good position because no disputed area between sharia scholars on existing I-REITs as required by the regulatory framework, which means sharia compliant is not a problematic issue (Chuweni \& Ahmad, 2014). This condition is also supported by large shareholding which enable good control of management from shareholders

IJIEF: International Journal of Islamic Economics and Finance, 2(1), 21-46 | 32 
Indrawan \& Wahyuningsih | Literature Review on REITs and Islamic REITs and Lessons Learned for Islamic REITs in Indonesia

and liquid capital market that enhance management's transparency and reduce agency cost (Zainuddin \& Nordin, 2016).

Other studies have tried to find empirical evidence of I-REITs performance, most of them are cases of Malaysia(Akinsomi et al., 2016; Chuweni \& Eves, 2017; Ma'in et al., 2016; Mohamad \& Saad, 2012; A. Osmadi \& Razali, 2014; Rozman, Azmi, Ali, et al., 2015; Teh et al., 2012; Yahya et al., 2016). One example is a study by (Rozman, Azmi, Ali, et al., 2015) that found some benefits of holding I-REITs instead of other asset classes such as shares and bonds. I-REITs in Malaysia during 2008-2014 period provided higher average annual returns compared to shares and bonds, but with lower risk-to-returns ratio. Another benefit is I-REITs is found to have little correlation with bonds and shares, which make it suitable for portfolio diversification. In other words, I-REITs is a profitable, safe and independent vehicle of investment. Typical study by (Rozman, Azmi, Razali, et al., 2015) echoed above result by stating that, in post-GFC event, I-REITs performed better compared to the conventional counterpart by also providing a higher degree of diversification for investors. In terms of performance determinants, a study by (Ma'in et al., 2016) found that macroeconomic variables (inflation and interest rate) are insignificant factors, and only firm size that significantly determine I-REITs performance in Malaysia, Singapore and Kuwait.

In general, some notable findings on I-REITs performance and risks are as following. First, the emergence of I-REITs is still a new phenomenon in Islamic Financial industry since the first world I-REITs was established in Malaysia, in 2006. Second, Malaysia is still the dominant market of I-REITs with some other new I-REITs also emerged from GCC, notably Bahrain, Kuwait as well as Singapore (Ma'in et al., 2016).Third, sharia issues within application of I-REITs have been solved by regulatory framework and sharia scholars so far.Fourth, I-REITs has well-performed by far compared to other asset classes and conventional REITs with performance is positively and significantly determined by I-REITs' firm size.

\section{Analysis}

\section{Regulatory Framework of REITs in Indonesia}

REITs (DIRE/Dana Investasi Real Estat in Bahasa Indonesia) have been regulated in Indonesia since 2007. At the time, the government of Indonesia recognises the need to enable REITs establishment to boost investment, particularly in real estate sector and in turn to help boost economic growth(Molina \& Nugraha, 2016). During Joko Widodo's term as Indonesia' President in 2014, some new regulations, either by government or Otoritas Jasa Keuangan/OJK (Financial Services Authory/FSA) were enacted to 
Indrawan \& Wahyuningsih | Literature Review on REITs and Islamic REITs and Lessons Learned for Islamic REITs in Indonesia

support REITs development in Indonesia. They are:

1. Peraturan Pemerintah (Government Regulation) No. 40 year 2016 which regulates that capital gain tax on REITs is only at $0.5 \%$ (Republik Indonesia, 2016).

2. Peraturan OJK (FSA Regulation) No. 64/POJK.04/2017 on REITs which regulates important aspects of REITs, such as(Otoritas Jasa Keuangan, 2017):

a) A REIT should invest at least $80 \%$ of its portfolio to real estate properties, and the rest $20 \%$ can be in form of real estate related assets, money market instruments, other securities, or cash.

b) Direct investment by REIT on real estate property can be either in a finished property or under-construction property. But the fund manager should make sure that after sixth month, the latter type of property should have generated income and at most $10 \%$ of REIT's NAV.

c) Direct investment by REIT on real estate property is only permissible for property in Indonesian territory.

d) A REIT should distribute at least $90 \%$ of its annual return to the unit holders.

e) A REIT in its prospectus should disclose all information regarding its investment, including risk, appraisal method, taxation, etc.

3. Peraturan OJK No. 30/POJK.04/2016 on Islamic REITs which regulates important aspects of I-REITs in Indonesia as following(Otoritas Jasa Keuangan, 2016a):

a) An I-REIT should follow regulations on REITs like the conventional ones.

b) An I-REIT is only permitted to invest on real estate properties which already generating income. It is different from conventional REITs that permitted to invest in underconstruction real estate properties but they must generate income at six months after the REITs' investment.

c) An I-REIT should have sharia supervisory board like in other Islamic financial institutions.

d) An I-REIT cannot invest in a real estate property which more than $10 \%$ of its area is used for non-halal activities and generate more than $10 \%$ non-halal income

e) Non-halal income of an I-REIT should not be included as Net Asset Value (NAV) of the I-REIT by the investment manager. 
Indrawan \& Wahyuningsih | Literature Review on REITs and Islamic REITs and Lessons Learned for Islamic REITs in Indonesia

On the ground of fatwa or sharia opinions, although no specific fatwa on REITs or I-REITs in Indonesia, since I-REITs is part of trust fund, it is subject to the Fatwa Dewan Syariah Nasional (National Sharia Council Fatwa) No. 20/DSN-MUI/IV/2001 on Trust Fund (Dewan Syariah Nasional Majelis Ulama Indonesia, 2001).

\section{Critical Evaluation}

Above explanation shows that REITs market in Indonesia has been regulated well, even for I-REITs despite its current non-existence. The regulations have adressed central issues on REITs such as tax incentive, transparency, and minimum investment on real estate properties as in more advanced REITs markets.

However, up to now, only two REITs companies listed in Indonesia Stock Exchange. They are DIRE CIPTADANA PROPERTI RITEL INDONESIA and DIRE BOWSPRIT COMMERCIAL AND INFRASTRUCTURE, which the latter's status is inactive according to Indonesia Central Securities Depository and none of them are I-REITs (Kustodian Sentral Efek Indonesia, 2018). It is unparallel with Indonesia's huge potential on real estate market, due to high economic growth especially bussinesses in the capital city area of Jakarta and tourism activities in regions such as Bali (Hotradero, 2014). In the context of I-REITs, the first I-REITs operated in Indonesia is not Indonesian based but Malaysian instead. In 2012, Al-Aqar group, a I-REITs company from Malaysia owned two hospitals in Indonesia (Najeeb \& Vejzagic, 2013). In other words, Indonesia is still left behind in developing Islamic capital market, particularly I-REITS.

One possible reason behind this phenomena is low concern among Indonesian practitioners to develop I-REITs. This is due to little appetite among investors for this kind of investment(Najeeb \& Vejzagic, 2013). This condition can be explained by relate it with low literacy rate of Indonesian citizens to the capital market. According to National Survey on Financial Literacy and Inclusion 2016, conducted by OJK, the financial literacy rate of Indonesians on capital market is just $4.4 \%$, while the inclusion rate is even lower at $1.25 \%$. Islamic capital market is suffering much lower rate, with literacy rate and inclusion rate are $0.02 \%$ and $0.01 \%$ respectively. Same survey concluded thatfinancial understanding and involvement of most Indonesians dominated by the banking system with capital market, including Islamic capital market is still at little rate of literacy and inclusion (Otoritas Jasa Keuangan, 2016b).

Apart from low appetite from demand side, there is also one possible reason from supply side. It is because REITs in Indonesia is only possible to be established as Collective Investment Contract. This regulation is imposed on all regulatory of REITs (and I-REITs) in Indonesia (Otoritas Jasa Keuangan, 
Indrawan \& Wahyuningsih | Literature Review on REITs and Islamic REITs and Lessons Learned for Islamic REITs in Indonesia

2016a, 2017). This regulation implies that only fund manager can establish REITs and I-REITs. Meanwhile, other jurisdictions like Japan, Korea and US, REITs can be established by non-fund manager, especially developers who seek non-bank financing to fund their construction projects (Chiang \& Joinkey, 2006). Restrictive requirement on REITs and I-REITs should be reconsidered in order to enhance the supply of REITs in Indonesian market.

\section{Conclusion and Recommendation}

\section{Conclusion}

REITs as investment instrument has been widely regarded as a good vehicle of real estate investment due to cost efficiency, tax advantage, market transparency and liquidity capacity for real estate sector since it can provide alternative financing, especially when credit rationing is imposed by government. Also, REITs provide the unit or shareholders flexible investment instrument that consists of two components, features like stock (dividend and capital gain) with some exposure to real estate sector. US REITs market is by far the most developed REITs market, followed by South Korea, Taiwan, Japan, Australia, and Singapore.

Within the studied period, the most researched topic on REITs is REITs performance, with USA market is the most studied so far as it the most mature REITs market in the world. REITs performance behavior is found to be a hybrid of common stock and real estate. REITs performance is found to be irrational in nature since geographical proximity does not show significant impact on REITs performance. Also, REITs market is heavily affected by the 2008 financial crisis since real estate sector as the provider of underlying assets of REITs damaged from huge losses during the crisis. Other than the performance, literatures on conventional REITs focus on understanding on REITs, especially on its structure as well as investigation on the regulatory framework on REITs, including comparison among jurisdictions.

The existence of Islamic Financial Institutions (IFIs) such as Islamic Banks has triggered demand for sharia-compliant REITS (I-REITS) in order to provide Islamic-preferred investor with such flexible and attractive investment instrument but in accordance with sharia rulings. Malaysia by far is the dominant player in global I-REITs markets since the establishment of Al 'Aqar KPJ REITs as first I-REITs in the world, based in Malaysia. Most studies on IREITs are dominated by Malaysian cases, with scope ranging from regulatory framework to performance. In general, I-REITs has no sharia compliant issue by far and found to outperformed other asset classes (bonds, shares, and conventional REITs) with high diversification benefit. 
Indrawan \& Wahyuningsih | Literature Review on REITs and Islamic REITs and Lessons Learned for Islamic REITs in Indonesia

There are some lessons learned from this literature review for development and study of I-REITs in the future. First, study on Muslim countries with proper capital markets such as Indonesia, Saudi Arabia and Pakistan but lack of progress on I-REITs is a potential research field. By looking at regulatory framework requirements mentioned by (Alias \& Y, 2011; Quek \& Ong, 2008) then make comparison with those jurisdictions, we can come up with proposed solutions for existence of REITs markets in these jurisdictions. This is an important issue since these countries need alternative financing for infrastructure, including that related to real estate sectors.

Second, with regard to sharia compliant issues, the current settled condition of I-REITs sharia compliance aspect is a good avenue for innovation of IREITs, such as I-REITs as financing to develop waqf properties or to support "green" buildings like the case of Singapore. This concern will make I-REITs become a "beyond sharia compliant" investment due to its applicability to support sustainable development.

Third, empirical analysis on I-REITs focus on its performance, risk and its relation with macroeconomic shocks, particularly inflation and interest rate. There are two possible areas to be studied here. First, the relationship between I-REITs and economic growth in aggregate or in particular, real estate sector. This area is important since Islamic Finance is declared inseparable with real economic sectors. Second, future studies on I-REITS should look at more micro aspect of I-REITs management such as capital structure, ownership structure and cost structure in order to evaluate I-REITs operation and open paveway for its improvement. Also, studies on marketing aspect, especially I-REITs investors behavior and its determinants are important to open opportunity new I-REITs markets.

\section{Recommendation}

In the context of Indonesian I-REITs, it is an instrument in Islamic capital market that still left behind Islamic equities and sukuk. Despite strong institutional supports in form of regulations as well as potential real estate development in Indonesia, local practitioners still disregard I-REITs since little appetite among investors. However, since Malaysian based I-REITs (AIAqar) has been operated in Indonesia, it means there is potential market for I-REITs development, but huge efforts should be taken by stakeholders to enhance financial literacy and inclusion on capital market, including Islamic capital market, which in turn will trigger development of I-REITs.

In this regard, the Financial Services Authority (Otoritas Jasa Keuangan/OJK) as the regulator of Indonesia's stock market may consider to opening opportunities for non-fund manager establishments to set up REITs and I- 
Indrawan \& Wahyuningsih | Literature Review on REITs and Islamic REITs and Lessons Learned for Islamic REITs in Indonesia

REITs. Inability for non-fund managers, particularly the real estate developers to issue I-REITs according to the current regulatory framework hinders possibility for more supply of I-REITs product. Also, incentive for IREITs issuer may become a trigger to start this new Islamic capital market product.

Meanwhile, on the demand side, the Islamic finance practitioner must enhance the awareness, literacy and inclusion of the populace regarding IREITs market. One possible way to enhance awareness, literacy and inclusion is optimizing the role of Information and Communication Technology (ICT) such as internet and social media as well as integrating I-REITs products with other Islamic financial institutions' products, either from Islamic banks, takaful (Islamic insurance), etc to trigger the demand for the product.

Lastly, from above discussion, future research may analyze the factors related to the reluctance of practitioners to issue I-REITs in Indonesia that lead to its non-existence as well as the level of community understanding on I-REITs and their possible willingness on that product if realized. This issue is important to be considered since development of I-REITs will attract potential investors will appetite to invest in real estate market, provide financing for real estate sectors, which in turn will boost the economy as well as deepening the Islamic capital market in Indonesia. 
Indrawan \& Wahyuningsih | Literature Review on REITs and Islamic REITs and Lessons Learned for Islamic REITs in Indonesia

\section{References}

Akinsomi, O., Ong, S. E., Ibrahim, M. F., \& Newell, G. (2016). The idiosyncratic risks of a Shariah compliant REIT investor. Journal of Property Research, 31(3), 211-243. https://doi.org/10.1080/09599916.2013.841276

Al-Haj, N. H. Y. Y., \& Hashim, H. (2009). Empirical Trend On Factors That Influence The Institutional Investors Towards Investing In Malaysia Real Estate Investment Trusts: A Preliminary Study. Oxford Journal: An International Journal of Business \& Economics, 4(1), 7-17.

Alexander, J. C., Cheng, P., Rutherford, R. C., Springer, T. M., \& Alexander, J. C. (2013). Acquisition of equity REIT IPOs in the aftermarket. Managerial Finance, 39(8), 737-755. https://doi.org/10.1108/MF-Jul2012-0153

Alias, A., \& Y, S. T. C. (2011). PERFORMANCE ANALYSIS OF REITS: COMPARISON BETWEEN M-REITS AND UK-REITS. Journal of Surveying, Construction and Property Vol.2, 2(Special Issue), 38-61.

Aro-gordon, S. (2015). On Risk-adjusted Return Performance of Publicly Traded Real Estate Securities in an Emerging Market. International Journal of Recent Advances in Organizational Behaviour and Decision Sciences (IJRAOB), 1(3), 479-496.

Asteriou, D., \& Beigazi, K. (2013). Modeling of daily REIT returns and volatility. Journal of Property Investment \& Finance, 31(6), 589-601. https://doi.org/10.1108/JPIF-06-2013-0035

Bairagi, R. K., \& Dimovski, W. (2012a). The direct costs of raising external equity capital for US REIT IPOs. Journal of Property Investment \& Finance, 30(6), 538-562. https://doi.org/10.1108/14635781211264513

Bairagi, R. K., \& Dimovski, W. (2012b). The level of representative underwriting and the underwriting costs of REIT SEOs. Journal of Property Investment \& Finance, 30(1), 18-41. https://doi.org/10.1108/14635781211194782

Bene, J. D., Anderson, R. I., \& Zumpano, L. V. (2009). Performance differences in property-type diversified versus specialized real estate investment trusts ( REITs ). Review of Financial Economics, 18, 70-79. https://doi.org/10.1016/j.rfe.2008.04.001

Brobert, G. (2016). The global REIT market : initial-day performance of IPOs. Journal of European Real Estate Research, 9(3), 231-249. https://doi.org/10.1108/JERER-03-2016-0015

Brown, D. T. (2000). Liquidity and Liquidation: Evidence from Real Estate Investment Trusts. The Journal of Finance, 55(1), 469-485.

Campbell, R. D., \& Sirmans, C. F. (2002). Policy implications of structural options in the development of real estate investment trusts in Europe: Lessons from the American experience. Journal of Property Investment \& Finance, 20(4), 388-406. https://doi.org/10.1108/14635780210435065

Chiang, Y.-H., \& Joinkey, C.-K. (2006). Devising a Conducive Regulatory Framework for Hong Kong Real Estate Investment Trusts. Journal of Financial Management of Property and Construction, 11(2), 91-104.

Chuweni, S. N. N., \& Ahmad, S. H. (2014). The Neo-governance Model of Malaysian Islamic Real Estate Investment Trusts. Journal of Administrative Science, 11(2).

IJIEF: International Journal of Islamic Economics and Finance, 2(1), 21-46 | 39 
Indrawan \& Wahyuningsih | Literature Review on REITs and Islamic REITs and Lessons Learned for Islamic REITs in Indonesia

Chuweni, S. N. N., \& Eves, C. (2017). A review of efficiency measures for REITS and their specific application for Malaysian Islamic REITS. Journal of Islamic Accounting and Business Research, 8(1), 41-53. https://doi.org/10.1108/JIABR-03-2015-0007

Compton, W. S., Johnson, D. T., Kunkel, R. A., \& Compton, W. S. (2006). The turn-of-the-month effect in real estate investment trusts (REITs). Managerial Finance, 32(12), 969-980. https://doi.org/10.1108/03074350610710463

Corgel, J. B., Mcintosh, W., \& Ott, S. H. (1995). Real Estate Investment Trusts: A Review of the Financial Economics Literature Real Estate Investment Trusts: A Review of the Financial Economics. Journal of Real Estate Society, 3, 13-43.

Dewan Syariah Nasional Majelis Ulama Indonesia. Fatwa Dewan Syari'ah Nasional Nomor: 20/DSN-MUI/IV/2001 Tentang Pedoman Pelaksanaan Investasi untuk Reksa Dana Syari'ah (2001). Retrieved from https://tafsirq.com/media/90/pedoman-pelaksanaan-investasi-untukreksa-dana-syariah.pdf

Dimovski, B., Ratcliffe, C., \& Keneley, M. (2017). Another piece of the puzzle : REIT IPO underpricing after the financial crisis. Journal of Property Investment \& Finance, 35(3), 264-276. https://doi.org/10.1108/JPIF07-2016-0060

Dong, Z. (2012). Capital structure decisions of LPTs in a small economy. Journal of Property Investment \& Finance, 30(5), 493-504. https://doi.org/10.1108/14635781211256756

Escobari, D., \& Jafarinejad, M. (2016). Date stamping bubbles in Real Estate Investment Trusts. Quarterly Review of Economics and Finance, 60, 224-230. https://doi.org/10.1016/j.qref.2015.10.003

Ewing, B. T., \& Payne, J. E. (2005). The response of real estate investment trust returns to macroeconomic shocks. Journal of Business Research, 58, 293-300. https://doi.org/10.1016/S0148-2963(03)00147-4

EY. (2018). Global Perspectives, 2018 REIT Report.

Feng, Z., Ghosh, C., \& Sirmans, C. F. (2007). On the Capital Structure of Real Estate Investment Trusts (REITs). Journal Real Estate Finance Economic, 34, 81-105. https://doi.org/10.1007/s11146-007-9005-2

Hamzah, A. H., Rozali, M. B., \& Tahir, I. M. (2010). Empirical Investigation on the Performance of the Malaysian Real Estate Investment Trusts in PreCrisis, During Crisis and Post-Crisis Period. International Journal of Economics and Finance, 2(2), 62-69.

Han, B. (2006). Insider Ownership and Firm Value : Evidence from Real Estate Investment Trusts. Journal Real Estate Finance Economic, 32, 471-493. https://doi.org/10.1007/s11146-006-6963-8

Hartzell, J. C., Kallberg, J. G., \& Liu, C. H. (2008). The Role of Corporate Governance in Initial Public Offerings: Evidence from Real Estate Investment Trusts. Journal of Law and Economics, 51, 539-562.

Hartzell, J. C., Sun, L., \& Titman, S. (2014). Institutional investors as monitors of corporate diversi fi cation decisions: Evidence from real estate investment trusts th. Journal of Corporate Finance, 25, 61-72. https://doi.org/10.1016/j.jcorpfin.2013.10.006

Haslam, C., Tsitsianis, N., Andersson, T., \& Gleadle, P. (2015). Real Estate 
Indrawan \& Wahyuningsih | Literature Review on REITs and Islamic REITs and Lessons Learned for Islamic REITs in Indonesia

Investment Trusts (REITS): A new business model in the FTSE100. Accounting Forum, 39(4), 239-370. https://doi.org/10.1016/j.accfor.2015.10.003

Hassan, M. K., \& Aliyu, S. (2018). A Contemporary Survey of Islamic Banking Literature. Journal of Financial Stability, 34, 12-43. https://doi.org/10.1016/j.jfs.2017.11.006

Ho, K. H. D., Addae-dapaah, K., \& Peck, F. R. L. (2017). Cross-listing of real estate investment trusts (REITs). Journal of Property Investment \& Finance, 35(5), 509-527. https://doi.org/10.1108/JPIF-08-2016-0063

Ho, K. H. D., Rengarajan, S., \& Lum, Y. H. (2013). "Green" buildings and Real Estate Investment Trust's (REIT) performance. Journal of Property Investment \& Finance, 31(6), 545-574. https://doi.org/10.1108/JPIF03-2013-0019

Ho, K. H. D., \& Tay, S. J. (2016). REIT market efficiency through a binomial option pricing tree approach. Journal of Property Investment \& Finance, 34(5), 496-520. https://doi.org/10.1108/JPIF-01-2016-0004

Hotradero, P. (2014). DIRE/REITS: Gambaran Global dan Prospek Indonesia. Retrieved from https://www.ekon.go.id/berita/download/2377/1746/bahan-paparankepala-divisi-manajemen-informasi-dan-pengembangan-emiten-bursaefek-indonesia-poltak-hotradero.pdf

Huerta, D., Jackson, D. O., \& Ngo, T. (2015). Categorizing sentiment and its impact on REIT returns. Managerial Finance, 41(9), 958-973. https://doi.org/10.1108/MF-06-2014-0164

Hui, E. C. M., Yiu, C. Y., \& Yau, Y. (2007). Retail properties in Hong Kong : a rental analysis. Journal of Property Investment \& Finance, 25(2), 136146. https://doi.org/10.1108/14635780710733825

Ibrahim, M. F., Ong, S. E., \& Akinsomi, O. (2012). Practice briefing Shariah compliant real estate development financing and investment in the Gulf Cooperation Council. Journal of Property Investment \& Finance, 30(2), 175-197. https://doi.org/10.1108/14635781211206913

Ivanov, S. I. (2016). Study of REIT ETF beta. The Journal of Risk Finance, 17(3), 347-369. https://doi.org/10.1108/JRF-12-2015-0120

Kim, H., Gu, Z., \& Mattila, A. S. (2002). Hotel Real Estate Investment Trusts ' Risk Features and Beta Determinants. Journal of Hospitality and Tourism Research, 26(2), 138-154. https://doi.org/10.1177/1096348002026002004

Kim, J., \& Jang, S. S. (2012). Comparative analyses of hotel REITs : examining risk-return and performance characteristics. International Journal of Contemporary Hospitality Management, 24(4), 594-613. https://doi.org/10.1108/09596111211226842

Kustodian Sentral Efek Indonesia. (2018). DIRE List Indonesia.pdf. Retrieved July 12, 2018, from http://web.ksei.co.id/isin_codes/dire

Larson, S. J. (2005). Real Estate Investment Trusts and Stock Price Reversals. The Journal of Real Estate Finance and Economics, 30(1), 81-88.

Lee, C., Chien, M., \& Lin, T. C. (2012). Dynamic modelling of real estate investment trusts and stock markets. Economic Modelling, 29(2), 395407. https://doi.org/10.1016/j.econmod.2011.11.008

Lee, C. L., \& Lee, M. L. (2012). Hedging effectiveness of REIT futures. Journal of Property Investment \& Finance, 30(3), 257-281. 
Indrawan \& Wahyuningsih | Literature Review on REITs and Islamic REITs and Lessons Learned for Islamic REITs in Indonesia

https://doi.org/10.1108/14635781211223824

Lee, C. L., \& Ting, K. H. (2009). The role of Malaysian securitised real estate in a mixed-asset portfolio. Journal of Financial Management of Property and Construction, 14(3), 208-230. https://doi.org/10.1108/13664380911000440

Lee, M. L., \& Chiang, K. (2010). Long-run price behaviour of equity REITs: become more like common stocks after the early 1990s? Journal of Property Investment \& Finance, 28(6), 454-465. https://doi.org/10.1108/14635781011080302

Lee, M., \& Lee, M. (2003). Institutional involvement and the REIT January effect over time. Journal of Property Investment \& Finance, 21(6), 435449. https://doi.org/10.1108/14635780310508612

Lee, S. (2016). REITs and the Taper Tantrum. Journal of Property Investment \& Finance, 34(5), 457-464. https://doi.org/10.1108/JPIF-03-2016-0020

Lewis, M. K. (2010). Accentuating the positive: governance of Islamic investment funds. Journal of Islamic Accounting and Business Research, 1(1), 42-59. https://doi.org/10.1108/17590811011033406

Liow, K. H., \& Addae-dapaah, K. (2010). Idiosyncratic risk, market risk and correlation dynamics in the US real estate investment trusts. Journal of Housing Economics, 19(3), 205-218. https://doi.org/10.1016/j.jhe.2010.06.001

Loo, W. K., Anuar, M. A., \& Ramakrishnan, S. (2016). Integration between the Asian REIT markets and macroeconomic variables. Journal of Property Investment \& Finance, 34(1), 68-82. https://doi.org/10.1108/JPIF-122014-0070

Lu, C., Chen, T., \& Liao, H. (2014). Underlying asset liquidity , heterogeneously informed investors, and REITs excess returns. Managerial Finance, 40(1), 72-96. https://doi.org/10.1108/MF-062012-0128

Ma'in, M., Arifin, N. A. M., Firdaus, M., Hatta, M., Hashim, M. H., \& Isa, S. S. M. (2016). Determinants of Islamic Real Estate Investment Trust Performance. Advanced Science Letters, 22, 4321-4325. https://doi.org/10.1166/asl.2016.8137

Mi, L., Benson, K., \& Faff, R. (2016). Further evidence on idiosyncratic risk and REIT pricing: a cross-country analysis. Accounting Research Journal, 29(1), 34-58. https://doi.org/10.1108/ARJ-07-2013-0048

Mohamad, N. E. A. binti, \& Saad, N. M. (2012). Syariah REITs Vis-A-Vis Conventional REITs: An Analysis. International Journal of Academic Research in Business and Social Sciences, 2(7), 1-17.

Molina, K., \& Nugraha, P. (2016). Real Estate Investment Trusts (REITs) in Indonesia: an Overview. Retrieved from https://uk.practicallaw.thomsonreuters.com/Link/Document/Blob/lac8 fa23f482611e698dc8b09b4f043e0.pdf?targetType=PLCmultimedia\&originationContext=document\&transitionType=Document Image\&uniqueld=43a563ea-a190-4412-b899-

3992acbad591\&contextData=(sc.Default)\&i

Mukhlisin, M., \& Komalasari, R. (2018). Do You Capture Financial Crisis? Journal of Islamic Monetary Economics and Finance, 3(2), 245-292.

Nadiah, S., Ali, M., Halim, A., \& Noor, M. (2016). Hungry for housing : waqf real estate development - a social welfare alternative. In MATEC Web 
Indrawan \& Wahyuningsih | Literature Review on REITs and Islamic REITs and Lessons Learned for Islamic REITs in Indonesia

of Conferences (Vol. 66, pp. 1-10).

Najeeb, S. F., \& Vejzagic, M. (2013). Development, Growth and Challenges of Islamic Capital Markets: Comparative Insights from the Malaysian, Indonesian, United Arab Emirates and Brunei Markets. Journal of Emerging Economies and Islamic Research, 1(3), 1-38.

Nazlioglu, S., Gormus, A., \& Soytaş, U. (2016). Oil Prices and Real Estate Investment Trusts (REITs): Gradual-Shift Causality and Volatility Transmission Analysis. Energy Economics, 60, 168-175. https://doi.org/10.1016/j.eneco.2016.09.009

Olaleye, A., \& Ekemode, B. (2014). Integration between real estate equity and non-real estate equity. Journal of Property Investment \& Finance, 32(3), 244-255. https://doi.org/10.1108/JPIF-10-2013-0063

Olanrele, O. O., Said, R., \& Daud, M. N. (2014). Benchmark for REIT Performance in Malaysia Using Hedonic Regression Model. International Journal of Economics and Finance, 6(9), 165-176. https://doi.org/10.5539/ijef.v6n9p165

Olanrele, O. O., Said, R., \& Daud, M. N. (2015). Comparison of REIT Dividend Performance in Nigeria and Malaysia. African Journal of Business Management, 9(16), 608-614. https://doi.org/10.5897/AJBM2015.7855

Osmadi, A. B., \& Razali, M. N. (2014). Assessing the Financial and Management Strength of Islamic REIT during the Global Financial Crisis. Conference Paper, (October 2013). https://doi.org/10.13140/RG.2.1.5109.2965

Osmadi, A., \& Razali, M. N. (2014). ASSESSING THE FINANCIAL AND MANAGEMENT STRENGTH OF ISLAMIC REAL ESTATE INVESTMENT TRUSTS (I-REITS) DURING THE GLOBAL FINANCIAL CRISIS (GFC). PERINTIS E-Journal, 4(1), 48-69.

Otoritas Jasa Keuangan. Peraturan Otoritas Jasa Keuangan Nomor 30 /POJK.04/2016 Tentang Dana Investasi Real Estat Syariah Berbentuk Dana Kontrak Investasi Kolektif (2016). Retrieved from http://www.ojk.go.id/id/kanal/iknb/regulasi/lembaga-keuanganmikro/peraturan-ojk/Documents/SAL-POJK PERIZINAN FINAL F.pdf

Otoritas Jasa Keuangan. (2016b). Survei Nasional Literasi dan Inklusi Keuangan 2016. Survey Report. Retrieved from https://www.ojk.go.id/id/berita-dan-kegiatan/siaran-

pers/Documents/Pages/Siaran-Pers-OJK-Indeks-Literasi-dan-Inklusi-

Keuangan-Meningkat/17.01.23 Tayangan Presscon nett.compressed.pdf

Otoritas Jasa Keuangan. Peraturan Otoritas Jasa Keuangan Nomor 64 /POJK.04/2017 Tentang Dana Investasi Real Estat Berbentuk Kontrak Investasi Kolektif (2017). Retrieved from https://www.ojk.go.id/id/regulasi/Documents/Pages/Dana-InvestasiReal-Estat-Berbentuk-Kontrak-Investasi-Kolektif/SAL POJK 64 - DIRE.pdf Pellerin, S. R., Sabol, S. J., \& Walter, J. R. (2013). MBS Real Estate Investment Trusts: A Primer. Federal Reserve Bank of Richmond Economic Quarterly, 99(3), 193-227.

Piao, X., Mei, B., \& Zhang, W. (2017). Long-term event study of timber real estate investment trust conversions. Forest Policy and Economics, 78, 1-9. https://doi.org/10.1016/j.forpol.2016.12.009

IJIEF: International Journal of Islamic Economics and Finance, 2(1), 21-46 | 43 
Indrawan \& Wahyuningsih | Literature Review on REITs and Islamic REITs and Lessons Learned for Islamic REITs in Indonesia

Quek, M. C. H., \& Ong, S. E. (2008). Securitising China real estate : a tale of two China-centric REITs. Journal of Property Investment \& Finance, 26(3), 247-274. https://doi.org/10.1108/14635780810871623

Ratcliffe, C., \& Dimovski, W. (2012). REIT mergers and acquisitions : a metaanalysis. Journal of Property Investment \& Finance, 30(3), 241-256. https://doi.org/10.1108/14635781211223815

Republik Indonesia. Peraturan Pemerintah Republik Indonesia Nomor 40 Tahun 2016 Tentang Pajak Penghasilan Atas Penghasilan dari Pengalihan Real Estat dalam Skema Kontrak Investasi Kolektif Tertentu (2016). Retrieved from http://www.hukumonline.com/pusatdata/downloadfile/lt573d7c8f97a be/parent/lt573d7bec6b30d

Rozman, A. T., Azmi, N. A., Ali, H. M., \& Razali, M. N. M. (2015). THE PERFORMANCE AND SIGNIFICANCE OF ISLAMIC REITS IN A MIXEDASSET PORTFOLIO. Jurnal Teknologi, (December). https://doi.org/10.11113/jt.v77.6850

Rozman, A. T., Azmi, N. A., Razali, M. N., \& Ali, H. M. (2015). The Potential of Islamic Real Estate Investment Trusts in Malaysia. PERINTIS E-Journal, 5(2), 13-30.

Sah, V., \& Seagraves, P. (2012). IPO market timing: evidence from the operating performance of REITs. Journal of Property Investment \& Finance, 30(1), 58-68. https://doi.org/10.1108/14635781211194809

San, O., Heng, T. B., \& Pong, C. M. (2011). A STUDY ON THE PERFORMANCE OF MALAYSIAN REAL ESTATE INVESTMENT TRUSTS FROM 2005-2010 BY USING NET ASSET VALUE APPROACH. International Journal Economic Research, 2(1), 1-15.

Seiler, M. J., Lee, S. T., \& Seiler, V. L. (2003). International unsecuritized real estate: A comparison between NCREIF (US) and MTB- IKOMA (Japan). Property Management, 21(1), 63-81. https://doi.org/10.1108/02637470310464481

Teh, B. H., Soh, C. H., \& Yan, Y. L. (2012). Malaysian Real Estate Investment Trusts : A Performance and Comparative Analysis. International Journal of Economics and Finance, 4(5), 73-84. https://doi.org/10.5539/ijef.v4n5p73

Tsai, I.-C., \& Lee, C. (2012). The convergent behavior in REIT markets. Journal of Property Investment \& Finance, 30(1), 42-57. https://doi.org/10.1108/14635781211194791

Tsai, I. (2013). Volatility clustering, leverage, size, or contagion effects : The fluctuations of Asian real estate investment trust returns. Journal of Asian Economics, 27(700), 18-32. https://doi.org/10.1016/j.asieco.2013.04.010

Waggle, D., \& Moon, G. (2006). Mean-variance analysis with REITs in mixed asset portfolios: The return interval and the time period used for the estimation of inputs. Managerial Finance, 32(12), 955-968. https://doi.org/10.1108/03074350610710454

Yahya, M., Hussin, M., Husaini, N. H., Muhammad, F., \& Razak, A. A. (2016). Integration of Islamic real estate investment trusts in Malaysia : Is it an issue for investors ? Malaysian Journal of Society and Space, 12(7), 7582.

Yeboah, F. G., Ling, D. C., \& Naranjo, A. (2012). Information, uncertainty, and 
Indrawan \& Wahyuningsih | Literature Review on REITs and Islamic REITs and Lessons Learned for Islamic REITs in Indonesia

behavioral effects : Evidence from abnormal returns around real estate investment trust earnings announcements. Journal of International Money and Finance, 31, 1930-1952. https://doi.org/10.1016/j.jimonfin.2012.05.013

Yung, K., Li, D. D., \& Jian, Y. (2017). Managerial decision horizon and real estate investment trusts (REITs) Managerial decision horizon and real estate investment trusts (REITs ). Review of Behavioral Finance, 9(1), 63-78. https://doi.org/10.1108/RBF-06-2015-0026

Zainuddin, Z., \& Nordin, N. (2016). Addressing Governance Issue in Islamic Real Estate Investment (I-REITs): A Case Study for OIC CountryMalaysia. IJIB, 1(1), 60-75.

Zulkhibri, P. M. (2015). A Synthesis of Theoretical and Empirical Research on Sukuk. Borsa Istanbul Review, 15(4), 237-248. https://doi.org/10.1016/j.bir.2015.10.001 
Indrawan \& Wahyuningsih | Literature Review on REITs and Islamic REITs and Lessons Learned for Islamic REITs in Indonesia

This page is intentionally left blank

IJIEF: International Journal of Islamic Economics and Finance, 2(1), 21-46 | 46 